Актуальні проблеми розвитку економіки регіону. Вип 16. T.2

2. Левицький В. Розроблення системи підвищення економічної стійкості підприємства на основі соціальних стратегій розвитку підприємства. Будуємо нову Україну. 2010. №3. С. 238-245. URL: http://ekmair.ukma.edu.ua/bitstream/handle/123456789/4598/Levyts\%27kyy_Rozroblennya_systemy. pdf?sequence $=1$ \&isAllowed=y (дата звернення 30.10.2020)

3. Вініченко І., Крючок С. Економічна стійкість підприємства та ії складові. Агросвіт. 2016. № 24. URL: file:///C:/Users/Lenovo\%20S145/Downloads/agrosvit_2016_24_4.pdf (дата звернення 30.10.2020)

4. Melnychuk Yu. M. Application of systematic approaches to assessing the effectiveness of the bank in conditions of financial independence of the region. Economies' Horizons. 2019. № 1(8). p. 36-43. URL: http://eh.udpu.edu.ua/article/view/170023 (дата звернення 30.10.2020)

5. Державна служба статистики. Індекси промислової продукції. URL: http://www.ukrstat.gov.ua/ (дата звернення 30.10.2020)

6. Краснолуцька О.В. Аналіз функціонування та тенденцій організаційного розвитку харчової промисловості України. Економіка та управління національним господарством. 2019. №3 (14). C. 66-70.

7. Ткачук І.Г., Мельничук Ю.М. Господарський механізм мікрорівневого стратегічного розвитку незалежного регіону. Актуальні проблеми розвитку регіону. 2019. Вип. 15., Т. 2., с. 140-147.

8. Melnychuk Yu., Chyrva O.H., Chvertko L. A., Chyrva H.M., Berbets V.V. The Role of Management in the Financial Independence of the Region. Tem Journal. 2019. Vol. 8. (2). pp. 584-590.

\title{
References
}

1. Tkachenko, S. M. "The essence of economic stability of enterprises and its components." Efektyvna Ekonomika, 2011, www.economy.nayka.com.ua/?op=1\&z=1350 Accessed 30 Oct. 2020.

2. Levytskyi, V. "Development of a system for increasing the economic stability of the enterprise on the basis of social strategies for enterprise development.” Buduiemo Novu Ukrainu, no.3, 2010, pp. 238245.

ekmair.ukma, ekmair.ukma.edu.ua/bitstream/handle/123456789/4598/Levyts\%27kyy_Rozroblennya_systemy.pdf?s equence=1\&isAllowed=yAccessed 30 Oct. 2020.

3. Vinichenko, I. \& S.Kriuchok (). "Economic stability of the enterprise and its components". Ahrosvit, no.24, 2016, agrosvit_2016_24_4.pdf. Accessed 30 Oct. 2020.

4. Melnychuk, Yu. M. "Application of systematic approaches to assessing the effectiveness of the bank in conditions of financial independence of the region.” Economies' Horizons, no.1(8), 2019, pp. 36-43. eh.udpu, eh.udpu.edu.ua/article/view/170023. Accessed 30 Oct. 2020.

5. "Industrial production indices." State Statistics Service, www.ukrstat.gov.ua/Accessed 30 Oct. 2020.

6. Krasnolutska, O.V. "Analysis of the functioning and trends of organizational development of the food industry of Ukraine.” Ekonomika Ta Upravlinnia Natsionalnym Hospodarstvom, no. 3 (14), 2019, pp. 66-70.

7. Tkachuk, I.H. \& Yu.M.Melnychuk ."Economic mechanism of micro-level strategic development of the independent region.” Aktualni Problemy Rozvytku Rehionu, no. 15 (2), 2019, pp. 140-147.

8. Melnychuk, Yu., Chyrva, O.H., Chvertko, L. A., Chyrva, H.M., and V.V. Berbets. "The Role of Management in the Financial Independence of the Region.” Tem Journal, no.8. (2), 2019, pp. 584590.

УДК 338.242

doi: 10.15330/apred.2.16.178-188

\section{ОСНОВНІ НАПРЯМИ ДЕРЖАВНОЇ ПІДТРИМКИ ЕКОЛОГІЗАЦЇ̈ СІЛЬСЬКОГО ГОСПОДАРСТВА}

Уманський національний університет садівництва, Міністерство освіти і науки України, кафедра економіки, вул. Інститутська, 1, м. Умань, 20305,Україна, тел.: (04744) 3-22-26, 
Актуальні проблеми розвитку економіки регіону. Вип 16. T.2

e-mail: economica@udau.edu.ua

Анотація. Екологізація сільськогосподарського виробництва в сучасному світі стала однією із нагальних проблем розвитку суспільства поряд із проблемою продовольчої безпеки. Стаття спрямована на дослідження державної підтримки екологізації сільського господарства. Встановлено, що екологізація сільського господарства $\epsilon$ першочерговим завданням держави для приведення агровиробництва у відповідність до сучасних вимог щодо якості та безпечності. Державна підтримка екологізації вітчизняного сільського господарства на сьогодні знаходиться на початковому рівні.

Досвід ведення екологічного сільського господарства в розвинутих країнах світу демонструє необхідність здійснення державою різновекторних інституційних та організаційноекономічних заходів, а також широке застосування фінансових інструментів державного регулювання. Пропонуємо систематизувати інструменти державної підтримки екологізації аграрної сфери економіки за такими групами: пряма державна підтримка (субсидії, дотації, пільгові кредити тощо); непряма державна підтримка (наукові дослідження, консультативноінформаційні послуги, лабораторні дослідження i т.д.); формування відповідного інституційного забезпечення (сертифікація виробництва та продукції; дотримання вимог щодо наявності у продукції нітратів, застосування пестицидів, агрохімікатів, добрив та ГМО, утилізації відходів).

Доведено, що надзвичайно важливим фінансовим інструментом державної підтримки екологізації аграрної сфери економіки, є збереження «зеленого тарифу» для виробників біоенергії з альтернативних джерел. Розроблені пропозиції державної підтримки сільського господарства у напрямку екологізації галузі.

Ключові слова: сільське господарство, екологізація, державна підтримка, сталий розвиток.

\title{
Burliai A.P., Revutska A.O. MAIN DIRECTIONS OF STATE SUPPORT FOR ECOLOGIZATION OF AGRICULTURE
}

\author{
Uman National University of Horticulture, \\ Ministry of Education and Science of Ukraine, \\ Department of Economics, \\ Instytutska str., 1, Uman, \\ 20305, Ukraine, \\ tel.: (04744) 3-22-26, \\ e-mail: economica@udau.edu.ua
}

\begin{abstract}
The ecologization of agricultural production in the modern world has become one of the urgent problems of society, along with the problem of food security. The article is focused on studying state support for ecologization of agriculture. It is established that the ecologization of agriculture is the primary task of the state to bring agricultural production in line with modern requirements for quality and safety. State support for the ecologization of domestic agriculture is currently at an early level.

The experience of organic agriculture in the developed countries of the world demonstrates the need for the state to implement various institutional and organizational and economic measures, as well as the widespread use of financial instruments of state regulation. We propose to systematize the tools of state support for the greening of the agricultural sector of the economy by the following groups: direct state support (subsidies, grants, soft loans, etc.); indirect state support (research, consulting and information services, laboratory research, etc.); formation of appropriate institutional support (certification of production and products; compliance with the requirements for the presence of nitrates in products, the use of pesticides, agrochemicals, fertilizers and GMOs, waste disposal).

It is proved that an extremely important financial instrument of state support for the ecologization of the agricultural sector of the economy is the preservation of the "green tariff" for
\end{abstract}


Актуальні проблеми розвитку економіки регіону. Вип 16. T.2

bioenergy producers from alternative sources. Proposals for state support of agriculture in the direction of ecologization the industry have been developed.

Key words: agriculture, greening, state support, sustainability.

Вступ. Сталий розвиток нині є ключовою концепцією розвитку України, яка передбачає комплексне вирішення економічних, екологічних та соціальних проблем суспільства. В цьому контексті екологізація сільського господарства $є$ першочерговим завданням держави для приведення агровиробництва у відповідність до сучасних вимог щодо якості та безпечності. Важливість державного регулювання у вирішенні згаданих проблем полягає також у подоланні суперечностей між екологічними та економічними критеріями ефективності функціонування галузі, зважаючи на безпосередню залежність сільського господарства від довкілля і навпаки.

Постановка завдання. Метою статті є дослідження головних аспектів державної підтримки екологізації сільського господарства в країнах Європейського Союзу та Україні, проведення класифікації інструментів державної підтримки галузі.

Теоретичною та методологічною основою дослідження є діалектична теорія пізнання і системний підхід до вивчення економічних явищ і процесів, теоретичні положення вітчизняних і зарубіжних учених із питань державної підтримки сільського господарства.

Наукові дослідження проводилися 3 використанням таких методів: монографічного, діалектичного, системно-аналітичного, абстрактно-логічного, порівняльного тощо.

Результати. Досвід ведення екологічного сільського господарства в розвинутих країнах світу демонструє необхідність здійснення державою різновекторних інституційних та організаційно-економічних заходів, а також широке застосування фінансових інструментів державного регулювання. Більше того, можна із впевненістю стверджувати, що екологізація сільського господарства, формування органічного сектору в агровиробництві європейських країн $\epsilon$ результатом цілеспрямованої дії держави.

Так, наприклад, стрімкий розвиток органічного виробництва у Франції та Німеччині був спричинений формуванням відповідної законодавчо-нормативної бази в 90-х роках XX століття та значною фінансовою підтримкою галузі урядами країн та СС у вигляді субсидій на виробництво екологічної продукції, формування виробничозбутових ланцюгів, формування системи сертифікації виробництва та продукції тощо. Проте розмір цих субсидій значно відрізняється навіть в межах країни залежно від розміщення органічної ферми, розміру та фінансового обороту. За даними сайту Agencebio, у Франції субсидії на виробництво органічної продукції коливаються в межах 7600-30400 євро в рік. Крім цього, у деяких районах Франції передбачено субсидії для проведення сертифікації продукції та податкові кредити у сумі 2500 євро на одне агропідприємство на рік та додатково 400 євро на один гектар, але не більше 4 тис євро на господарство в рік [1].

За дослідженнями Н.П. Новак, у переважній більшості країн Європейського Союзу, проводиться субсидування виробництва органічної агропродукції в розрахунку на одиницю площі, проте в останні роки в деяких країнах (наприклад, в Нідерландах), субсидують не виробництво, а стимулювання попиту на екологічно чисту продукцію. Крім цього, в деяких країнах запроваджено компенсацію збитків в конверсійний період тощо [2].

В рамках програм розвитку сільського господарства в країнах $Є С$ виіляють такі основні інструменти державної підтримки його екологізації: 
Актуальні проблеми розвитку економіки регіону. Вип 16. T.2

- стимулюванні попиту на екологічну продукцію шляхом застосування нових програм якості;

- дії, спрямовані на збереження екологічних переваг та охорону природи в довгостроковій перспективі;

- створення стимулів для органічних фермерів 3 метою переходу на органічну систему господарювання всього підприємства, а не лише певного виду діяльності;

• створення можливостей для інвестиційної підтримки органічних фермерів;

- створення стимулів для виробників екологічної продукції для полегшення збуту продукції шляхом інтеграції всього виробничого ланцюга в (договірну) систему залучених сторін;

• підтримка консультаційних послуг;

- навчання та освіта для всіх суб'єктів екологічного землеробства, включаючи виробництво, переробку та маркетинг [3].

Приклади державної допомоги при здійсненні екологізації аграрної сфери економіки в європейських країнах наведені в табл. 1.

Таблиия 1

Особливості державної допомоги при екологізації сільського господарства в країнах $\mathrm{CC}$

Features of state aid for greening of agriculture in EU countries

\begin{tabular}{|c|c|}
\hline Країни & Економічні інструменти \\
\hline Австрія & $\begin{array}{l}\text { Субсидії в розмірі } 285 \text { євро на } 1 \text { га орної землі, } 450 \text { євро для трав } \\
\text { / спецій і овочів, за пасовища } 240 \text { євро, а пасічники отримують } \\
25 \text { євро на } 1 \text { вулик. Виробництво під покривами підтримується в } \\
\text { розмірі } 4200 \text { євро (теплиці) та } 2900 \text { євро / га (фольгові теплиці). }\end{array}$ \\
\hline Італія & $\begin{array}{l}\text { Визначено декілька пріоритетів для фінансування інвестицій у } \\
\text { рамках заходу «Модернізація сільськогосподарських } \\
\text { господарств» - органічне землеробство з акцентом на } \\
\text { садівництво, молочне виробництво, виробництво м'яса та } \\
\text { фруктів. Фінансування програм "Якість виробництва" та } \\
\text { "Інформаційна та промоційна діяльність" . Дотації становлять } \\
\text { 100-200 євро на } 1 \text { га. }\end{array}$ \\
\hline Великобританія & $\begin{array}{l}\text { Бюджет на агроекологічні заходи є низьким, що призводить до } \\
\text { низької підтримки з гектара (близько } 90 \text { євро на } 1 \text { гп), особливо } \\
\text { для органічних фермерів після періоду конверсії. }\end{array}$ \\
\hline Ірландія & $\begin{array}{l}\text { Субсидії на перетворення земельної ділянки становлять від } 212 \\
\text { євро з гектара на площі до } 55 \text { га, далі } 30 \text { євро; для переробленої } \\
\text { землі це } 106 \text { євро з гектара до } 55 \text { га та } 15 \text { євро пізніше. Для } \\
\text { господарств розміром менше } 6 \text { га плата за гектар становить } 283 \\
\text { євро за землю в період конверсії та } 142 \text { євро за екологічний стан. } \\
\text { Ці суми виділяються на гектар для "самостійних екологічних } \\
\text { заходів", які можуть бути поєднані за певних обставин із } \\
\text { заходами за схемою захисту сільського середовища (REPS), що } \\
\text { також є основним видом діяльності для звичайних фермерів. }\end{array}$ \\
\hline Швеція & $\begin{array}{l}\text { Встановлює пріоритети щодо інвестицій, що підтримують } \\
\text { постачання на ринок екологічних продуктів з доданою вартістю, } \\
\text { наприклад, на переробку сертифікованих органічних харчових } \\
\text { продуктів. Розмір субсидій для органічного агровиробництва } \\
\text { становить 144-244 євро на гектар. }\end{array}$ \\
\hline
\end{tabular}




\begin{tabular}{|l|l|}
\hline \multirow{4}{*}{ Чеська республіка } & Підтримка в рамках агроекологічної програми для ріллі, \\
& постійних пасовищ, овочів, трав в розмірі 155 євро на гектар. \\
Загальний бюджет Програми розвитку сільського господарства & для органічного землеробства становить 19,83 млн. євро \\
Органічне землеробство є загальним пріоритетом Чеської & програми розвитку сільського господарства. Органічні фермери \\
отримують кращу підтримку через прогами "Модернізація \\
сільськогосподарських господарств", "Підвищення доданої \\
вартості основного сільськогосподарського та \\
лісогосподарського виробництва" та "Сприяння старту молодих \\
фермерів", «Диверсифікація на несільськогосподарські види \\
діяльності» та «Підтримка туристичної діяльності».
\end{tabular}

* - сформовано автором на базі джерела [3]

В країнах Свропейського Союзу прийнято САП (Спільну аграрну політику), яка складається з двох частин:

1) фінансування екологічних проектів фермерами лише після виконання вимог Сприятливих умов для сільського господарства та довкілля (Good agricultural and environmental condition, GAEC) для сільськогосподарських товаровиробників;

2) цільове спрямування виплат на виконання конкретної екологічної програми.

Згідно із положеннями САП на період 2014-2020 рр. частка бюджету СС, спрямованого на вирішення екологічних та кліматичних проблем та на перехід до органічного та дружнього до навколишнього середовища сільського господарства становить 28,9 \% до загального бюджету СС або 119 млрд євро [4].

Підходи країн ЄС до екологічного регулювання аграрного виробництва включають в себе взаємну підтримку «cross-compliance» та адміністративний підхід.

Cross-compliance - це система надання субсидій 3 бюджету $\mathrm{CC}$ сільськогосподарським товаровиробникам за дотримання низки вимог, що стосуються захисту довкілля, якості продуктів харчування і належного поводження з худобою. Найпоширенішими прямими субсидіями такої системи $\epsilon$ єдина субсидія на сільськогосподарські угіддя, субсидія на сільськогосподарські практики, що сприяють збереженню навколишнього природного середовища та захисту клімату, субсидія молодим виробникам та субсидія для районів з природними обмеженнями. В країнах ЄС прямі виплати за даною системою є доступними для всіх фермерів, які виконують базові вимоги стандартів харчової безпеки, добробуту тварин та збереження довкілля [5].

Адміністративний підхід регулювання екологічними процесами в сільському господарстві заключається у дотриманні вимог прийнятих директив стосовно нітратів, пестицидів та агрохімікатів, утилізації відходів тощо [6].

Напрями державної регулювання сільського господарства у сфері екологізації можна поділити на три групи:

I - пряма державна підтримка, інструменти якої безпосередньо стосуються виробників і безпосередньо сприяють впровадженню екологічних елементів у виробництво - субсидії, дотації, пільгові кредити тощо;

II - непряма державна підтримка, методи якої стосуються спонукання до впровадження елементів екологізації, а саме наукові дослідження, консультативноінформаційні послуги, лабораторні дослідження і т.д.;

III - інституційне забезпечення - сертифікація виробництва та продукції; дотримання вимог щодо наявності у продукції нітратів, застосування пестицидів, агрохімікатів, добрив та ГМО, утилізації відходів [7]. 
Актуальні проблеми розвитку економіки регіону. Вип 16. T.2

Державна підтримка екологізації вітчизняного сільського господарства на сьогодні знаходиться на початковому рівні, тому корисним буде провести класифікацію iii основних інструментів на основі досвіду розвинутих країн (рис. 1).

\begin{tabular}{|c|c|c|}
\hline \multicolumn{3}{|c|}{ Інструменти державної підтримки екологізації аграрної сфери економіки } \\
\hline пряма державина підтримка & $\begin{array}{c}\text { непряма державна } \\
\text { підтримка }\end{array}$ & $\begin{array}{c}\text { інстипуциійне } \\
\text { забезпечення }\end{array}$ \\
\hline субсидії, дотації & $\begin{array}{c}\text { популяризація та } \\
\text { субсидування стимулювання } \\
\text { попиту споживання } \\
\text { екологічної продукції } \\
\end{array}$ & $\begin{array}{c}\text { формування екологічної } \\
\text { політики держави }\end{array}$ \\
\hline пільгове кредитування & розвиток інфраструктури & $\begin{array}{c}\text { екологічне законодавство та } \\
\text { його гармонізація із } \\
\text { законодавством інших країн }\end{array}$ \\
\hline $\begin{array}{c}\text { інвестування, цільові } \\
\text { програми розвитку }\end{array}$ & наукові дослідження & $\begin{array}{c}\text { сертифікація виробництва та } \\
\text { продукції }\end{array}$ \\
\hline пільгове оподаткування & $\begin{array}{c}\text { консультативно-інформаційні, } \\
\text { дорадчі послуги }\end{array}$ & $\begin{array}{c}\text { формування стратегій, } \\
\text { концепцій та програм } \\
\text { розвитку }\end{array}$ \\
\hline державні закупівлі & лабораторні дослідження & $\begin{array}{c}\text { державний нагляд (контроль) } \\
\text { за дотриманням } \\
\text { законодавства у сфері } \\
\text { органічного виробництва та } \\
\text { обігу органічної продукції }\end{array}$ \\
\hline $\begin{array}{c}\text { режим прискореної } \\
\text { амортизації } \\
\text { природоохоронних фондів }\end{array}$ & $\begin{array}{c}\text { запровадження екологічного } \\
\text { страхування }\end{array}$ & $\begin{array}{c}\text { встановлення } \\
\text { відповідальності за } \\
\text { порушення екологічного } \\
\text { законодавства }\end{array}$ \\
\hline $\begin{array}{c}\text { преміальні виплати за } \\
\text { підвищення екологічних } \\
\text { якостей продукції, за } \\
\text { поліпшення екологічного } \\
\text { контролю виробництва, за } \\
\text { зниження забруднень і } \\
\text { впровадження безвідходних } \\
\text { технологій }\end{array}$ & $\begin{array}{c}\text { підтримка кластерних } \\
\text { ініціатив і розвиток } \\
\text { органічної кооперації }\end{array}$ & \\
\hline $\begin{array}{c}\text { відшкодування витрат на } \\
\text { інспекцію та сертифікацію } \\
\text { органічної продукції }\end{array}$ & $\begin{array}{c}\text { субсидування участі в } \\
\text { конференціях, виставках } \\
\text { різного рівня }\end{array}$ & \\
\hline $\begin{array}{c}\text { стимулювання біоенергетики, } \\
\text { зелений тариф }\end{array}$ & $\begin{array}{c}\text { удосконалення інноваційних } \\
\text { екологічних технологій }\end{array}$ & \\
\hline цінові надбавки, компенсації & $\begin{array}{c}\text { розвиток сільських територій, } \\
\text { забезпечення зайнятості } \\
\text { сільського населення }\end{array}$ & \\
\hline
\end{tabular}

Puc. 1. Інструменти державної підтримки екологізації аграрної сфери економіки (узагальнено автором)

Fig.1. Instruments of state support for greening the agricultural sector of the economy (summarized by the author)

Насамперед, підтримка екологізації аграрної сфери економіки залежить від якісного інституційного забезпечення даних процесів, серед якого необхідно виділити 
Актуальні проблеми розвитку економіки регіону. Вип 16. T.2

формування екологічної політики держави та прийняття відповідного законодавчого забезпечення.

Побудова інноваційної економіки при дотриманні принципів сталого розвитку є вимогою сучасної державної політики. Сталий розвиток означає стабільне економічне зростання, пов'язане 3 раціональним управлінням екологічними ресурсами та дотриманням прав людини. Саме людина має бути найвищою цінністю в екологічній політиці держави через спрямованість на якість життя, здоров'я та добробут. Тому, роль екологічної політики полягає у забезпеченні екологічної безпеки держави. Це повинно бути відображено у відповідних структурах державного управління на національному, регіональному та місцевому рівнях і в такому розподілі компетенцій та завдань, що дозволять встановлювати цілі на кожному рівні на основі визнання потреб, а засоби їх досягнення вибираються 3 урахуванням критерії екологічної та економічної ефективності.

Екологічна політика держави на 2030 рік також повинна підтримувати реалізацію цілей та зобов'язань України на міжнародному рівні, особливо в контексті цілей кліматичної та енергетичної політики та трьох конвенцій Ріо: кліматичної конвенції, Конвенції про біологічне різноманіття та Конвенції про опустелення.

Відповідно до екологічної політики держави створюється належне законодавче забезпечення, стратегії, концепції та програми розвитку екологізації галузі.

Щодо інструментів прямої державної підтримки екологізації сільського господарства в Україні, то вони регулюються Законом України «Про основні принципи та вимоги до органічного виробництва, обігу та маркування органічної продукції», в якому зазначено, що державна підтримка може надаватися операторам органічного ринку у рамках загальнодержавних та регіональних програм за рахунок і в межах видатків за бюджетними програмами, спрямованими на підтримку розвитку сільськогосподарських товаровиробників.

У бюджеті України на 2020 рік передбачено фінансування аграрної сфери економіки за статтями:

фінансова підтримка заходів в агропромисловому комплексі - 5000,0 тис грн;

фінансова підтримка сільгосптоваровиробників - 4000 000,0 тис грн;

підвищення кваліфікації фахівців агропромислового комплексу - 24 343,3 тис грн.

Тобто пряма державна підтримка екологізації сільського господарства на загальнодержавному рівні можлива лише в рамках державної підтримки підприємств галузі без пріоритету проведення різноманітних екологічних заходів та здійснення екологічного виробництва, що, звісно, не сприятиме вирішенню екологічних проблем в контексті сталого розвитку суспільства та не відносить екологічні проблеми до нагальних проблем держави.

В ряді областей країни прийняті регіональні програми у сфері екологізації агровиробництва, які передбачають фінансову підтримку екологічних проектів в різних сферах сільського господарства. Так, Комплексною програмою підтримки та розвитку агропромислового виробництва Львівської області передбачено відшкодування фінансових витрат у вигляді часткової компенсації витрат з проведення сертифікації органічного виробництва та заготівлі органічних об'єктів рослинного світу в розмірі фактичних витрат, але не більше ніж 20 тис грн одному суб'єкту господарювання.

У Чернігівській області прийнята Програма фінансової підтримки органічного виробництва в Чернігівській області на 2015-2020 роки. Вона розроблена на виконання законів України «Про безпечність та якість харчових продуктів», «Про виробництво та обіг органічної сільськогосподарської продукції та сировини» та плану заходів, затверджених розпорядженням голови Чернігівської облдержадміністрації «Про розвиток виробництва та ринку органічної продукції в Чернігівській області» від 
06.11.2014 року №646. Завданням Програми є зменшення собівартості виробництва органічної продукції за рахунок компенсації затрат виробника на проведення сертифікації виробництва (сировини, продукції) та здешевлення вартості органічної продукції 3 метою забезпечення іiі конкурентоздатності на внутрішньому та зовнішньому ринках. Виконання Програми буде здійснюватись за рахунок коштів обласного бюджету протягом 2015-2020 років і загальна потреба в коштах обласного бюджету складає 1,5 млн гривень.

Обласна програма розвитку агропромислового комплексу Кіровоградської області на 2018-2023 роки також передбачає фінансування екологічних програм. Це стосується фінансової підтримки суб'єктів господарювання в галузі сільського господарства, фізичних осіб у вигляді дотації на площу угідь, на яких проводитимуться заходи із збереження та відтворення родючості грунтів в розмірі 12 млн грн. Крім цього передбачено фінансову підтримку на зворотній основі у вигляді короткострокових (терміном на 1 рік) та середньострокових (терміном на 3 роки) кредитів надаються суб'єктам господарювання агропромислового комплексу, сільськогосподарським кооперативам, фізичним особам на на витрати, пов'язані з виробництвом органічної продукції за рахунок обласного бюджету. Фінансова підтримка надається учасникам на платній та зворотній основі: у розмірі до 200 тис грн терміном на 1 рік та до 500 тис грн терміном до 3 років з відстроченням повернення основної суми зобов'язання до одного року.

Аналогічні програми регіонального рівня прийняті у багатьох областях України та передбачають використання різноманітних фінансових інструментів 3 метою екологізації сільського господарства та сприяння його сталому розвитку.

Проте, на думку сільськогосподарських товаровиробників, зважаючи на нагальність проблеми, державна підтримка екологізації агросфери $\epsilon$ вкрай недостатньою. Пропонується поряд із зазначеними інструментами державної допомоги застосовувати також:

- відміну податку на доходи фізичних осіб при сплаті орендної плати за користування землею для ведення товарного сільськогосподарського органічного виробництва та зниження податкового навантаження на час перехідного періоду в органічному виробництві. Це буде суттєвою конкурентною перевагою, котра зможе забезпечити більший рівень орендної плати власникам органічної землі;

- надання спеціального статусу сертифікованій органічній землі та створення умов довгострокової та стабільної оренди земель під органічним виробництвом;

- впровадження Державної програми по харчуванню органічними продуктами в закладах освіти;

- створення механізму закладам освіти закупівлі місцевих продуктів від органічних фермерів. Розробка спрощеного порядку закупівлі продукції харчування для дітей та підлітків у місцевих органічних агровиробників, особливо у фермерів;

- розробка системи просування споживання органічної продукції за іміджевої, інформаційної та фінансової підтримки, наприклад, соціальна реклама про важливість вживання органічної продукції для споживача й органічного виробництва для сталого сільського господарства та створення соціальних ініціатив для промоції органічних продуктів харчування;

- підтримка кластерних ініціатив і розвиток органічної кооперації [8].

Надзвичайно важливим фінансовим інструментом державної підтримки екологізації аграрної сфери економіки, на наш погляд, є збереження «зеленого тарифу» для виробників біоенергії з альтернативних джерел. Адже ця виплата не лише сприяє екологізації галузі, а й впливає на енергетичну безпеку країни загалом. Так, з 2015 року в Україні були введені в дію об’єкти відновлювальної енергетики, що працюють за 
Актуальні проблеми розвитку економіки регіону. Вип 16. T.2

«зеленим тарифом» потужністю 2943 МВт - з 999 МВт в 2015 році до 3910 МВт в 2019 році. При цьому лише 117 МВт виробляється з сільськогосподарської сировини біомаси та біогазу. На сьогодні в країні встановлені лише 43 біогазові установки потужністю 66 MBт, що є надзвичайно низьким показником. Тому, на наш погляд, зелений тариф стимулюватиме розвитку альтернативних джерел енергії в сільському господарстві.

В Україні «зелений» тариф був законодавчо закріплений лише в 2008 році. На даний момент він регулюється Законом України «Про електроенергетику», а також низкою інших нормативних та підзаконних актів. «Зелений» тариф - це спеціальний тариф, за яким держава закуповує електроенергію по завищеній ціні у підприємств і приватних осіб, що використовують альтернативні джерела енергії.

Відповідно до Закону України «Про внесення змін до деяких законів України щодо забезпечення конкурентних умов виробництва електричної енергії 3 альтернативних джерел енергії» від 25.04.2019 року [9], «зелений» тариф на електричну енергію, вироблену споживачами, у тому числі енергетичними кооперативами, з енергії сонячного випромінювання, енергії вітру, біомаси, біогазу, 3 використанням гідроенергії, геотермальної енергії генеруючими установками, встановлена потужність яких не перевищує 150 кВт, встановлюється єдиним для всіх споживачів, у тому числі енергетичних кооперативів, за кожним видом альтернативного джерела енергії.

Законом визначені коефіцієнти «зеленого» тарифу для електроенергії, виробленої з використанням альтернативних джерел енергії (табл.2).

Таблиия 2

Коефіцієнти «зеленого» тарифу для електроенергії, виробленої 3 використанням альтернативних джерел енергії в сільському господарстві

Table 2

Green tariff coefficients for electricity produced using alternative energy sources in agriculture

\begin{tabular}{|c|c|c|c|c|c|}
\hline Показники & $\begin{array}{c}3 \\
01.04 .2013 \\
\text { по } \\
31.12 .2014 \\
\end{array}$ & $\begin{array}{c}3 \\
01.01 .2015 \\
\text { по } \\
30.06 .2015 \\
\end{array}$ & $\begin{array}{c}3 \\
01.07 .2015 \\
\text { по } \\
\text { 31.12.2019 } \\
\end{array}$ & $\begin{array}{c}3 \\
01.01 .2020 \\
\text { по } \\
31.12 .2024 \\
\end{array}$ & $\begin{array}{c}3 \\
01.01 .2025 \\
\text { по } \\
31.12 .2029 \\
\end{array}$ \\
\hline $\begin{array}{l}\text { Електроенергія, } \\
\text { вироблена } 3 \\
\text { біомаси }\end{array}$ & 2,30 & 2,07 & 2,30 & 2,30 & 2,30 \\
\hline $\begin{array}{l}\text { Електроенергія, } \\
\text { вироблена } 3 \\
\text { біогазу }\end{array}$ & 2,30 & 2,07 & 2,30 & 2,30 & 2,30 \\
\hline
\end{tabular}

Сформовано автором за даними джерела [9]

Дані таблиці показують, що відповідно до законодавства України на період до 2030 року в аграрному секторі економіки буде збережено «зелений тариф» для електроенергії, виробленої з біомаси та біогазу, на відміну від скорочення тарифів на енергію з інших альтернативних джерел. Він складає 12,39 €ct/кВт·год.

Разом 3 цим, необхідно зазначити деякі пропозиції, що вимагають державної підтримки:

- відміна акцизного податку на біодизель та на рідкі біопалива, що є частиною сумішевих моторних палив та відповідають критеріям сталості (при дотриманні науково-обгрунтованого співвідношення між біокомпонентами та іншими складовими);

- створення ринкового механізму торгівлі біопаливом; 
- для прозорості ринку здійснювати торгівлю біопаливом через електронну систему торгівлі біопаливом;

- сприяння створенню генеруючих потужностей різних форм власності, в т.ч. на кооперативних засадах в сільському господарстві;

- розробка регуляторних заохочувальних механізмів для впровадження біоенергетичних проектів;

- впровадження освітньої програми з еко-інновацій тощо.

Висновок. Таким чином, вищевикладене дозволяє зробити висновок, що не зважаючи на екологічну політику України в контексті сталого розвитку, державна підтримка екологізації аграрної сфери економіки на разі знаходиться на низькому рівні та потребує вдосконалення, що матиме не лише екологічний ефект, а й економічний та соціальний. Визначено основні інструменти державної підтримки екологізації аграрної сфери економіки за такими групами: пряма державна підтримка (субсидії, дотації, пільгові кредити тощо); непряма державна підтримка (наукові дослідження, консультативно-інформаційні послуги, лабораторні дослідження і т.д.); формування відповідного інституційного забезпечення (сертифікація виробництва та продукції; дотримання вимог щодо наявності у продукції нітратів, застосування пестицидів, агрохімікатів, добрив та ГМО, утилізації відходів).

1. La bio en France de la production a la consummation. URL: http://www.agencebio.org/. (дата звернення 15.03.2017).

2. Новак Н.П. Світовий досвід державної підтримки виробництва органічної продукції. Ефективна економіка. №6. 2016. URL: http://www.economy.nayka.com.ua/?op=1\&z=5034. (дата звернення 19.03.2018).

3. Pohl A. Przyszłość Rolnictwa Ekologicznego w Europie: Jak europejskie Programy Rozwoju Obszarów Wiejskich wspierają rolnictwo ekologiczne? IFOAM EU GROUP. Bruksela, 2009. URL: www.ifoam-eu.org. (дата звернення 09.05.2017).

4. Милованов Є.В. Найкращі світові практики державної підтримки органічного сільськогосподарського виробництва та перспективи для України. Механізм регулювання економіки. 2018. № 2. С. 14-33.

5. Урбан І. Хубер Б., Дмитрова К. Можливості державної підтримки для розвитку органічного сільського господарства. Досвід інших країн. Київ: Дослід. ін-т орган. землеробства (FiBL, Швейцарія), Біоінститут (Чеська Республіка), 2013. 122 с.

6. Почкун О., Баськов О. Управління екологічними та соціальними ризиками. Евроінтеграиійні фактори. URL: https://bakertilly.ua/news/id46508. (дата звернення 07.12.2019).

7. Бурляй А.П. Організачійно-економічні засади екологізаџї̈ аграрної сфери економіки Украӥни: монографія. Умань. Видавець «Сочінський М.М.», 2019. 348с.

8. Білоусова Н. «Біблія» органічного виробництва: як зміниться ринок після 2 серпня із введенням закону №2496-VIII. Сайт AgroPolit.com. URL: https://agropolit.com/spetsproekty/577bibliya-organichnogo-virobnitstva-yak-zminitsya-rinok-pislya-2-serpnya-iz-vvedennyam-zakonu2496-viii. (дата звернення 30.06.2019).

9. Закон України «Про внесення змін до деяких законів України щодо забезпечення конкурентних умов виробництва електричної енергії з альтернативних джерел енергії» від 25.04.2019 року. Відомості Верховної Ради (ВВР). 2019. № 23. ст.89.

\section{References}

1. La bio en France de la production a la consummation. agencebio, www.agencebio.org/. Accessed 15 Mar. 2017.

2. Novak, N.P. "World experience of state support of organic production." Efficient economy, no.6, 2016, www.economy.nayka. com.ua/ ?op=1\&z=5034. Accessed 19 Mar.2018.

3. Pohl, A. Przyszlość Rolnictwa Ekologicznego w Europie: Jak europejskie Programy Rozwoju Obszarów Wiejskich wspieraja rolnictwo ekologiczne? Bruksela, IFOAM EU GROUP, 2009, www.ifoam-eu.org. Accessed 09 May 2017.

4. Milovanov, E.V. "The best world practices of state support of organic agricultural production and prospects for Ukraine.” The mechanism of economic regulation, no. 2, 2018, pp. 14-33. 
Актуальні проблеми розвитку економіки регіону. Вип 16. T.2

5. Urban, I. Huber, B., and K. Dmitrova. Opportunities for state support for the development of organic agriculture. Experience of other countries. Kyiv: Experiment. int body. of Agriculture (FiBL, Switzerland), Bioinstitute (Czech Republic), 2013.

6. Pochkun, O., and O. Baskov. "Environmental and social risk management. European integration factors.” bakertilly, bakertilly.ua/news/id46508. Accessed 07Dec.2019.

7. Burliai, A.P. Organizational and economic principles of greening the agricultural sector of the economy of Ukraine: monograph. Uman. Publisher "Sochinsky MM", 2019.

8. Bilousova, N. "Bible" of organic production: how the market will change after August 2 with the introduction of the law №2496-VIII. Website AgroPolit.com, agropolit.com/spetsproekty/577-bibliyaorgani chnogo-virobnitstva-yak-zminitsya-rinok-pislya-2-serpnya-iz-vvedennyam-zakonu-2496-viii. Accessed 30Jun. 2019.

9. "Law of Ukraine "On Amendments to Certain Laws of Ukraine on Ensuring Competitive Conditions for Electricity Production from Alternative Energy Sources" of April 25, 2019." Information of the Verkhovna Rada (VVR), no.23, 2019, pp.89.

УДК 33:631.1

doi: 10.15330/apred.2.16.188-199

\title{
ІНВЕСТИЦЙНА ПРИВАБЛИВІСТЬ СІЛЬСЬКОГОСПОДАРСЬКИХ ПІДПРИЕМСТВ РЕГІОНУ
}

\author{
${ }^{1}$ ДВНЗ “Прикарпатський національний \\ університет імені Василя Стефаника", \\ Міністерство освіти і науки України, \\ кафедра фінансів, \\ м. Івано-Франківськ, вул. Шевченка, 57, \\ 76018, Україна, \\ тел.: 0342752351, \\ e-mail: omelyant@ukr.net \\ 2 ДВНЗ "Калуський політехнічний коледж" \\ вул. Б.Хмельницького, 2, м.Калуш, \\ 77303, Україна, \\ тел.: (03472) 6-52-31, \\ e-mail: kpk.kalush@gmail.com
}

\begin{abstract}
Анотація. У представленій статті уточнено сутність і зміст інвестиційної привабливості сільськогосподарських підприємств регіону. 3 точки зору теорії позикових коштів, при аналізі ринку капіталу застосовується неокласична методологія, яка досліджує фактори, що визначають попит, пропозицію і рівновагу на ринку.

Відзначено, що інвестиційна привабливість - найважливіший фактор активізації інвестиційної діяльності в сільському господарстві регіону. Інвестиційна привабливість розглядається як комплексна соціально-економічна характеристика об'єкта 3 об'єктивних i суб'єктивних факторів, що дозволяє інвесторові прийняти рішення про доцільність інвестування.

Виявлено, що оцінку інвестиційної привабливості сільськогосподарських підприємств регіону слід проводити з урахуванням особливостей виробництва, економічного становища, в якому перебуває сільське господарство в даний момент, а також рівня та ефективності державної підтримки. Інвестиційна привабливість містить в собі дві складові: інвестиційний потенціал і інвестиційний ризик, які втілюють в собі цілу низку приватних показників.
\end{abstract}

